\title{
Delegative Democracy in Russia and Ukraine
}

\author{
Paul Kubiček \\ Department of Political Science, University of Michigan, Ann Arbor MI 48109 \\ $U S A$
}

This paper applies the concept of delegative democracy to contemporary developments in Russia and Ukraine. They qualify as examples of this phenomenon insofar as leaders in these states are elected by the people but use their democratic legitimacy to justify authoritarian behavior. Factors which contribute to this trend are a deep socio-economic crisis, existent political culture, and a lack of institutions to safeguard democratic norms. While recognizing the various arguments endorsing this solution, this paper concludes that this form of rule is unlikely to live up to its promises and ultimately undermines the emergence of a representative, pluralist democracy.

In recent years, the former communist states of the Soviet bloc have joined several Southern European, Latin American, and Asian states in a tidal wave of democratization. The study of this phenomenon has become a growth industry, both within post-communist studies and comparative politics more generally (Bernhard, 1993; Bova, 1991; Di Palma, 1990; Diamond and Plattner, 1993; Diamond et al., 1988; Ekiert, 1991; Huntington, 1991; O’Donnell et al., 1986; Przeworski, 1991). At the same time, however, it has become apparent that existing theories and typologies of democracy, based upon the representative, pluralist model of developed Western countries, may be inappropriate to describe and explain regime transition and consolidation in a number of states. These nations may have developed systems which meet the minimal requirements of the genus demokratiya but share little in common with the extant Western democratic species. ${ }^{1}$

For some, this poses little problem, as nations such as Brazil, Peru, Russia, and Ukraine are labeled "partially democratic." It is argued, however, that we may be witnessing a "new animal," one born out of historical conditions and the severity of the socio-economic crisis gripping several states in transition, including many in the former Soviet bloc. This creature is a hybrid, a mixture of selected democratic norms of majoritarian rule and authoritarian practice.

Borrowing from Guillermo O'Donnell, this phenomenon is labeled "delegative democracy" (O'Donnell, 1992, 1993). This paper will apply this concept to political developments in Russia and Ukraine, two post-communist states caught in the

1. These requirements are that leaders are elected through competitive elections with universal suffrage, which fulfills the Schumpeterian definition of democracy (see Schumpeter, 1950). 


\section{Delegative Democracy in Russia and Ukraine: P. Kubiček}

throes of acute crisis, although similarities can probably be found with other East European states and former Soviet republics. Employment of this notion forces us to transcend the focus on the holding of free elections, and to consider political developments more holistically and assess the "quality" of democracy.

The idea of "delegative democracy" touches upon a fundamental theme in postcommunist development: can reform and liberal democracy be pursued simultaneously? While many in the West may offer a hopeful "yes" to this question, one could certainly argue that one priority should give way to the other. After all other options are proven to be unworkable, "delegative democracy" may be the last standing option, the least of several evils.

This paper is divided into three parts. First, the features of delegative democracy and factors which promote its emergence are described. Second, trends in Russia and Ukraine which fall under the rubric of delegative democracy are highlighted. Finally, reflection is made upon the consequences of these developments, which will allow us to determine if this phenomenon may be a genuine solution to the problems these states are facing or an impediment to further democratization.

\section{Delegative Democracy: Principles and Causes}

A delegative democracy is one which meets the formal requirements of democracy, but whosc actual practice resembles that of an authoritarian statc. It is grounded on a basic premise: the elected president is entitled to govern the country as s/he sees fit for the duration of the term to which s/he has been elected. The rule of law, a hallmark of Western democratic practice, is not well-respected. Typically, presidents in delegative democracies present themselves as above all parties and politics, since they alone can claim to represent and embody the entire nation. Delegative democracy is strongly majoritarian: a majority, through elections, empowers an individual to become the sole interpreter of the interests of the nation. This type of rule, however, is not commonly assumed to be democratic. In practice, it gives the president free reign to act as $s /$ he pleases and to justify activities in the name of the people. Its closest cousin is the subtype of authoritarianism known as Caesarism, Bonapartism, or caudillismo (O'Donnell, 1992, pp. 6-7).

Delegative democracy is distinguished from representative democracy, the Western model, by differing notions of accountability. Representation, of course, involves an element of delegation, since elected officials are entitled to speak for their constituencies, who have "delegated" them power. Representation, however, entails the idea of accountability, that the "delegate" is held responsible for the ways in which s/he acts. In consolidated Western democracies, accountability operates not only directly vis-à-vis voters, but also horizontally through other institutions which "have the capacity of calling into question and eventually punishing 'improper' ways of discharging the responsibilities of the given officer" (O'Donnell, 1992, p. 9).

Delegative democracy does not per se deny the notion of accountability, but it does not possess the level of institutionalization which facilitates it. ${ }^{2}$ The elected

2. Institutionalization refers to the degree that regularized patterns of interaction are engrained in the political arena and respected by social actors. These include both constitutional or statutory provisions and organizations (parties, courts, legislatures) with well-established roles. Institutions help stabilize the political environment by creating shared expectations and establishing common norms, principles, and decision-making rules. 
president is formally accountable to the electorate, but this provides little restraint because institutions are too feeble to check presidential power and recall is difficult if not impossible. Parties, courts, and interest groups may criticize presidential actions, but these are ignored as an unnecessary impediment to the full authority the president has been delegated by the nation. In some cases, elected presidents have reversed themselves after being elected-they promise one thing and do its opposite-but no one is able to prevent this. ${ }^{3}$ In short, the president uses his/her election by the entire people as a means to legitimize his/her own policies and discredit opposition as sectoral, disruptive, or even unpatriotic. Delegation therefore includes "the right-actually the obligation-of applying to the nation the tough medicines that, even though many of its members cannot recognize it now, will heal it" (O'Donnell, 1992, p. 8). In practice, these cures are prescribed by state technocrats, who are protected by the president and shielded from popular pressures.

O'Donnell points to two factors which have contributed to the emergence of delegative democracies in contemporary Latin America: historical inexperience with democracy and a deep socio-economic crisis. The former militates against the presence of a political culture supportive of democratic principles. This functions at the elite, institutional, and mass levels. At the elite level, memories of democracy presumably are conducive to the re-animation of principles of compromise and moderation, which inhibit pure, unrestrained presidentialism. Institutionally, previous democratic expcricnce makes it casicr for political parties and effective legislatures to re-emerge since they do not have to be constructed from scratch. At the mass level, those who are complete strangers to democracy may not have the requisite skills or political efficacy to believe that they can or should influence politics. Delegation to a supreme authority is, in a sense, "easier," and continues the tradition of paternalistic government. Adding these factors together, O'Donnell argues that redemocratization in the cases of Uruguay and Chile is far easier than building democracy on a complete authoritarian historical foundation (O'Donnell, 1992, p. 11).

Widespread crisis in society poses an additional barrier to the establishment of Western-style democracy. Crisis generates a sense of urgency, which requires a government of saviors. "Medicine" must be quickly shoved down suciety's throat, regardless of what it would prefer. Advocates of delegative democracy may argue that anti-crisis measures-including the establishment of law and order and perhaps painful social and economic reforms-cannot be adopted through tradeoffs and compromises characteristic of pluralist, representative democracy, which is too beholden to special interests and vagaries of public opinion. This type of democracy, which "institutionalizes uncertainty," (Przeworsky, 1986, p. 58) is too risky because it makes the adoption of "correct" policies problematic if not impossible. Delegative democracy, on the other hand, insulates decision-makers from political pressures so they may adopt policies without regard to popular outcry. Moreover, delegative democracy promises swift policy-making, a sharp contrast to the snail-like processes endemic to most consolidated Western democracies.

At this point it should be clear that this concept may be useful in the postcommunist environment. With the exception of Czechoslovakia, no post-commu-

3. This phenomenon is not unique to delegative democracies, i.e. Bush's "Read my lips" pledge. Yet, because leaders in delegative democracies have shorter time horizons due to the imperatives of crisis and are free from checks by any party or other institutions, they have more leeway for this type of maneuver. 
nist state has memories of democracy. Democratic institutions, therefore, had to be created for the first time, and in many cases they remain on shaky ground, competing with remnants of the old system. Vestiges of a Leninist political culture-including unwillingness to compromise, faith in etatism, low levels of trust, lack of popular initiative-remain (Jowitt, 1992; Bujvol, 1992). Public opinion polls reveal that immediate solutions to the socio-economic crisis-not more democratization-are the top priority for many individuals. This environment is ripe for political demagoguery, as would-be autocrats can play upon society's fears. This, of course, varies according to the depth of the crisis in each country. The Czech Republic, Hungary, and Poland are thus better candidates for Western style democracy than, for example, Romania, Albania, Russia, or Ukraine. ${ }^{4}$

Endorsements of solutions which correspond to delegative democracy (or myaky [soft] authoritarianism ${ }^{5}$ ) abound in the Russian and the Ukrainian press. Referring to the "Latinoamerikanizatsiya" of society, one Russian political scientist suggested that Russia could be rescued by an "Iron Fist-Friend of the People," analogous to a Just Tsar. This "democratic Caesar" is necessary to force economic reform upon society (Kuzmishchev, 1993). One economist in Ukraine argued that democratic ideals were "romantic-heroic" but "inappropriate for life at the end of the twentieth century." Democratic "chatterboxes" should therefore yield the political stage to experts who can act in the country's best interests and assuage the economic crisis (Pochentsov, 1993). The deputy minister of finance suggested that a strong political force must emerge which will assume the obligation of telling the people the harsh truth and implementing reform despite protests from below (Post-Postup, 1993a). One member of the Liberal Party declared, "Ukraine does not need a Parliament. It needs a strong President with a team of well-qualified advisors" (Korotsei, 1993). Reflecting a faith in expertise and distrust of politics, the Pinochet model has emerged in both states as a strong competitor to Western pluralism and liberalism. ${ }^{6}$

I propose that we turn now to developments in Russia and Ukraine and examine to what extent these appeals are being made political reality.

\section{Manifestations of Delegative Democracy}

Russia

After the successful defeat of communist hard-liners in the ill-fated putsch of August, 1991, there was hope that President Boris Yeltsin would succeed in guiding Russia through the arduous transition to the market and democracy. He introduced a series of reforms in 1992. These changes, however, have been accompanied by-some would say caused-declining standards of living for many Russians and sparked a political backlash. Squabbles between conservative forces in the Congress of People's Deputies and the president threatened to derail reform and paralyse the Russian state. These culminated in the dissolution of parliament and the return of tanks to the streets of Moscow. Yeltsin's actions in the autumn

4. An excellent source for comparative public opinion is the World Value Survey, most recently conducted in 1990-1991. Ronald Inglehart at the University of Michigan kindly provided me access to this data.

5. In numerous interviews in Ukraine, this frequently arose as a favored solution to the current crisis. 6. In Ukraine I was informed that "Fans of Pinochet" clubs exist in many cities. Unfortunately, I was unable to investigate them. 
of 1993 reveal most clearly movement toward delegative democracy (Migranyan, 1993).

These developments, however, should not have come as a complete surprise to astute observers of Russian politics. Conflict had been brewing for some time. Throughout 1992, the pace of reform, the composition of the government, and constitutional changes proved to be sources of friction between Yeltsin and the Russian parliament. The Congress, headed by Ruslan Khasbulatov, passed a series of constitutional amendments designed to restrict Yeltsin's powers. Yeltsin's decree banning the activities of arch-conservatives, especially the National Salvation Front, was declared unconstitutional by the Constitutional Court. Some aides urged Yeltsin to dissolve parliament and impose direct presidential rule, while others sought a compromise through a national referendum. In March, 1993, the Congress rejected proposals for power-sharing and a referendum, and Yeltsin responded by issuing a decree of "special rule," which placed him above the legislature. This sparked widespread opposition and an attempt at impeachment, which narrowly failed. Seeking to defuse this political crisis, both sides agreed to hold a national referendum, which asked Russians if they had confidence in the president, supported his policies, and wanted early presidential and parliamentary elections. The results of the April 25 plebiscite were a moral victory for Yeltsin, but a majority of all eligible voters failed to support his call for early parliamentary elections. ${ }^{7}$

The political climate heated up in the summer of 1993. Yeltsin's supporters and opponents blamed each other for political gridlock and deteriorating economic conditions, and exchanged charges of corruption. Parliament continued to adopt laws, decrees, and resolutions which threatened Yeltsin's reforms. Regional leaders and political bodies chose sides between Yeltsin and the Congress. The state was virtually paralysed.

The pot finally boiled over on September 21 when Yeltsin issued the decree "On Gradual Constitutional Reform in Russia," which called for the dissolution of parliament, direct presidential rule for three months, and elections for a newly created State Duma. The Constitutional Court, parliament, and even many proreform forces declared this move unconstitutional. Yeltsin then supported his initial decree by suspending the Constitutional Court, closing a number of newspapers, imposing temporary censorship on all remaining periodicals, and banning the activities of a number of opposition groups. He also ordered the dissolution of local councils throughout Russia, claiming these bodies were a block to reform. Their powers were assumed by local executives appointed by the president. The nation was brought to the brink of civil war as parliament refused to disband and called on the army for support. Yeltsin, with the crucial support of the military and security forces, eventually forced his opponents to yield after parliament was shelled and stormed, producing numerous casualties.

Yeltsin's next move was to schedule a national referendum on his draft of a new constitution, which was to be held on the same day as the vote for the State Duma. This draft, published barely a month before the referendum, was "not the product of public consent or political compromise but the embodiment of the President's

7. Exact figures for the vote can be found in ITAR-TASS (1993). Sixty-four per cent of eligible voters took part in the referendum. Of these, 58 per cent said they had confidence in the president, 53 per cent expressed support for his policies, 67 per cent wanted new parliamentary elections, and just over 50 per cent were in favor of early presidential elections. These last two provisions required a majority of all eligible voters to become legally binding, and this did not occur. 
will" (Lysenko, 1993, p. 1), and many feared that it could establish the basis for an authoritarian regime in Russia. In brief, this document gives the presidency the upper hand in the Russian political arena. He enjoys wide powers of appointment and the right to dissolve the State Duma. He may declare a state of emergency which does not require approval, but only "confirmation" by the Council of Federation, the upper legislative chamber. ${ }^{\circ}$ He may dismiss the government without approval of the State Duma. Impeachment procedures exist, but are rather cumbersome. The relationship between the center and the republics strongly favors Moscow. One observer declared that the Fundamental Laws of 1906 gave Tsar Nicholas II less power than the proposed constitution (Ustyuzhanin, 1993). Nonetheless, amid charges of electoral irregularities, the constitution was approved by a bare majority of voters on December 12, 1993 (Slater, 1994). ${ }^{9}$

These actions, which exhibit a strong authoritarian character, fall under the rubric of delegative democracy. Yeltsin was popularly elected, and the results of the April, 1993, referendum further bolstered his claim to be the voice of the people. While admitting that his September decree was unconstitutional, he explicitly referred to his prior mandate, claiming that the parliament had trampled on the will of the people expressed in the referendum and that "the security of Russia and its peoples is more precious than formal compliance with the contradictory norms established by a legislative power that has definitely discredited itself" (Izvestia, 1993a, p. 1). ${ }^{10}$ Throughout this period, Yeltsin put himself above party politics, constantly justifying his actions as for the good of the Russian people.

The problem should be clear. Yeltsin, while formally accountable to "the people," assumed monopoly right to interpret their collective will. The slogan, "The people's opinion is above the law," became a staple in the rhetoric of Yeltsin's supporters, which, since Yeltsin is the interpreter of their opinion, means that Yeltsin need not worry about the legal legitimacy of his actions (Pastukhov, 1993). Yeltsin has branded his opponents--even those of the centrist Civic Union-as communists or fascists (Tolz, 1993). Meanwhile, he has put himself above reproach, operating on the principle, "The state-it is I." This is indicative of a broader elite political culture, which includes elements of dilettantism, the inability to reach compromises, the unwillingness to listen to each other, and the readiness to discredit opponents by any means necessary, endemic in Russia today (Kuvaldin, 1993).

Yeltsin has found significant support for his policies. One writer accused the intelligentsia of serving as provocateur and instigator of Yeltsin's anti-democratic actions (Shokhina, 1993). These "democrats" sacrificed legality for the sake of political expediency. From March until October, members of the intelligentsia repeatedly urged the President to declare a state of emergency and attack opponents in parliament (Wishnevsky, 1993). Yeltsin received high levels of public support (68-72 per cent) throughout the crisis in October (Cline et al., 1993). This does not necessarily mean that the public actively supported the use of force, but it can be taken to mean that, at minimum, the public resigned itself to Yeltsin's actions as a necessary step. Moreover, one should not forget about the role played

8. It is not immediately clear from the document that the state of emergency can be rescinded by this body.

9. Aside from the weakly substantiated charge of government tampering with ballots, the opposition also claimed that state media campaigns made the vote unfair. Political parties, for example, were prohibited from using delegated airtine to criticize the draft constitution or the president.

10. Yeltsin, of course, conveniently forgot about the majority of April voters who endorsed early presidential elections. 
by the army and security organs, whose entrance into the political arena may raise concern about Russia's political future.

Yeltsin's actions were facilitated by a lack of institutions powerful enough to instill and maintain respect for the law. The Constitutional Court, which sided with parliament (for legal and political reasons), was circumvented by legal means by Yeltsin in the first half of 1993. Yeltsin also stripped its head of his state dacha and security service (Slater, 1993). Its activities were then suspended when politically expedient. Recent legislation will further limit the powers of the Court to rule on issues that irked Yeltsin in the past (Nezavisimaya Gazeta, 1994a). The Ministry of Justice, ostensibly empowered to enforce the law, issued a puzzling comment that "although he [Yeltsin] did go beyond legal boundaries, he acted in accordance with the constitutional principles of democracy" (Slater and Tolz, 1993, p. 3). Both Yeltsin and his opponents argued that the 1978 Soviet Constitutionlegally supreme until the Russian Constitution was approved-was outdated and could therefore be ignored. This created a major problem, since an established separation of powers between the executive and legislative branches, in addition to judicial independence, did not exist. Violations of the constitution were routine, and a plethora of amendments were passed as political actors saw fit. Rule by decree replaced the rule of law. ${ }^{11}$ Political parties were in a poor position to counter Yeltsin's moves. They were-and are-weak, lack organization, resources, and stable constituencies, and are more tied to individual personalities than any particular program. Until very recently, Yeltsin was the very personification of reform, and therefore it was difficult for parties interested in reform to distance themselves from the President. Moreover, since Yeltsin himself is not a member of any party, it makes it more difficult for fledgling political parties to exercise much influence on him.

Civic organizations also lack the power to counter rule imposed from above. Many were-and still are-allied to the pro-Yeltsin Democratic Russia movement. Business associations in the umbrella group Civic Union, along with their centrist allies, were unable to dissuade Yeltsin from his agenda of disbanding parliament by any means necessary. The labor movement, despite strikes in some regions, has been unable to organize itself into a coherent, potent political force. The Federation of Independent Unions of Russia, a holdover from the communist era which represents 90 per cent of all unions, is anti-Yeltsin and a proponent of slower reform. However, it has been unable to mobilize its members or effectively link itself with other parties or movements (Izvestia, 1993b). According to one report, "the actual workings of the union movement are so chaotic that it is impossible to understand who represents who, who is protected, who can be mobilized, and who are impostors," and most members of the federation do not even know about its existence (Izvestia, 1994, p. 4).

Finally, one can find support for delegative democracy in public opinion surveys. According to polls conducted in November, 1993, a month before the election, only 25 per cent of the electorate was familiar with the programs of different political parties. Over half were not familiar with the platform of the party for which they intended to vote (Corning, 1993). This means that voters continue to have a personalized view of politics, voting for personalities over policies. This makes accountability more difficult because political platforms become less important.

11. In 1992, Yeltsin issued 1727 decrees and 811 directives, and in the first six months of 1993 the respective numbers were 955 and 460 . Khasbulatov also issued a high number of decrees and personal directives. Meanwhile, in 1992 the Supreme Soviet passed only 112 laws (see Gualtieri, 1993). 
"Delegates" are not bound to them-since voters do not know about them-so they may do as they want. One survey in May, 1993, revealed that 66 per cent of Russians thought Russia needed a strong leader to control parliament. Later, in October, half of respondents to one survey favored the emergence of a "strong hand" to restore order (Izvestia, 1993c). This, no doubt, reflects frustration with the existent "democracy" and a desire for simple and effective solutions to restore social and economic order. More disturbing for any form of democracy are the actual results of the December elections, in which Zhironovsky's LiberalDemocratic Party won the most votes by party list and communists also fared well.

What are we to make of these trends? Does delegative democracy have a future in Russia? One can point to some recent events which may signal the decline of this form of rule. The State Duma, in which pro-Yeltsin forces are outnumbered by his opponents, has convened, and Yeltsin has bowed to pressure and appointed more conservatives to the government. Yeltsin himself has for unknown reasons receded somewhat from the political landscape, and Prime Minister Viktor Chernomyrdin has emerged as a major figure. Former Yeltsin allies are discussing formation of a new party which will be pro-reform but not dependent upon Yeltsin (Nezavisimaya Gazeta, 1994b). Finally, the new constitution, while far from perfect, does specify a division of powers and establishes an independent judiciary.

These are positive signs, but the political future of Russia is far from certain. Zhironovsky's recent success is cause for alarm, and the possibility of his winning the presidency is most unsettling. Meanwhile, "democrats" of a more Western orientation-Gaidar and Yavlinsky-were defeated at the polls and are not a part of the current government. Yeltsin and the State Duma are working together, but the risk of acrimony between him and a more conservative parliament recalls the experience of last autumn. There is no steadfast guarantee that constitutional provisions will be respected since democratic traditions and institutions remain weak. Recently, Yeltsin has again taken to rule by decree on the issues of ministerial appointments, which directly contradicts the approved Constitution which reserves this power to the prime minister (Tolz, 1994). Finally, and probably most importantly, much will be decided by economic and social conditions in the country. If they fail to improve, calls for a "strong hand" will likely grow louder. Yeltsin has already demonstrated his willingness to heed that call. In short, conditions in Russia make the development of an institutionalized, stable democracy precarious at best.

\section{Ukraine}

Ukraine may be an even more fertile ground for delegative democracy than Russia. Since winning independence in 1991, Ukraine has plunged into a deep economic crisis. Production and GDP dropped by almost 20 per cent in both 1992 and 1993, while inflation in 1993 jumped to over 10000 per cent (Post-Postup, 1994). Public opinion surveys regularly reveal widespread levels of dissatisfaction and little confidence in the future. ${ }^{12}$ By most measures, Ukraine is faring worse than Russia. This is supported by two pieces of anecdotal evidence: the Russian ruble is considered hard currency in Ukraine and the verb "to Ukrainianize"

12. According to one survey of 1000 Ukrainians conducted in early 1993,73 per cent of the respondents stated they were not satisfied with their current lives. In another poll of 1400 citizens, only 24.28 per cent expected conditions to improve during 1993. Both surveys were conducted by the Instilute of Sociology of the Ukrainian Academy of Sciences. I would like to thank Eugene Sinnitsyn of Socialinform for providing me with access to this data. 
(ukrainizirovat) has entered the Russian vocabulary with a pejorative meaning. Meanwhile, public confidence in organs of state power has fallen throughout 1993 in response to continued stagnation and a perception that there are too many political games being played in Kiev (Ukrainsky Ohlyadach, 1994). In short, both within the state and in society at large there is a growing recognition that the time for political debates is over and that concrete solutions and strong leadership are needed to extricate Ukraine from crisis.

Politically, Ukraine has remained comparatively stable, as there has been no civil war, attempted coup d'etat, or hint of military intervention in political affairs. The most prevalent political theme throughout 1992-1993 was the effort of the "party of power" (Ryabchuk, 1992) or the "new nomenklatura" to consolidate and centralize power. The "party of power" refers to the former communists who have continued to dominate the upper echelons of Ukrainian politics. While its members may have formally surrendered their party cards, the "party of power" may be labeled "crypto-communist," that is, "it is characterized by economic and political conservatism, a penchant for authoritarianism and command-administrative methods, and clan connections." If the party before played a "leading and directing" role, the new "party" plays a "manipulative" one (Ryabchuk, 1994a, pp. 4-5). However, this elite is no longer a "comprador elite" or an administrative bureaucracy for Moscow. It has become a genuine Ukrainian elite, and it tries to present itself as the greatest defender of Ukrainian statehood.

President Leonid Kravchuk, the former idcology secretary of the Ukrainian Communist Party, is commonly assumed to be the head of the "party of power." Kravchuk was popularly elected in December, 1991, and since that time he has taken several steps along the path toward delegative democracy. Kravchuk, who lacks ties to any registered party, has consistently placed himself above politics, arguing that "all patriotic forces should be consolidated around the task of statebuilding, and overcome personal ambition and neglect 'insignificant' tactical discrepancies for the sake of a greater strategic goal" (Ryabchuk, 1994b). He accused opposition political parties of hindering a calm life and work by "speculating on workers and advancing private interests" (Post-Postup, 1993b, p. 3). Breaking a promise to hold a referendum of confidence on him and the legislature, Kravchuk claimed that proponents of a referendum "bring nothing to our people except trouble" (Holos Ukrainy, 1993a, p. 4). Meanwhile, he has placed himself above reproach, announcing that he (and his allies) "are" the state (Nezavisimost, 1993a).

This rhetoric has been supported by efforts to centralize power. In May, 1993, in the wake of a crisis of authority between himself and the prime minister, he took steps to concentrate all executive power in his own hands, trying to obtain the sweeping privileges enjoyed by other presidents in delegative democracies. He failed initially, but in September, 1993, he issued a presidential order and assumed leadership of the Cabinet of Ministers and placed his allies in power to create a team of "like thinkers" (Izvestia, 1993d). He extended his power through his appointed presidential representatives in the oblasts, who are accountable only to him and who have been accused of running their districts like a private fief. Like Yeltsin, he has shown a fondness for ruling by decree, and presidential orders on questions of social and economic policy are issued without public debate and are only printed post facto in official papers.

Although Kravchuk is the elected president, he is not the only example consistent with the precepts of delegated democracy. Former prime minister-now president-Leonid Kuchma shares much in common with Kravchuk. In November, 
1992, Kuchma was unanimously elected prime minister by the Verkhovna Rada, the Ukrainian parliament, and granted extraconstitutional powers to resolve the economic crisis. The Verkhovna Rada, in effect, "delegated" its decision-making powers to Kuchma because the former was unable or unwilling to assume responsibility for governance.

Kuchma, however, let it immediately be known that he was a manager, not a politician, and for him the word politics assumed a pejorative tone (Holos Ukrainy, 1993b; Nezavisimost, 1993b). ${ }^{13}$ He complained that politics dominated the economy, and asserted that people simply want to conduct their own affairs and are tired of political conversation. He maintained that he would serve as prime minister only if he was granted extraconstitutional powers, and he repeatedly threatened to resign if his cabinet was not approved in full or if his power was curtailed. He advised all political parties to go on a vacation-hopefully a long one-to let his executive authority work (Nezavisimost, 1993c). While he admitted that mistakes were made under his tutelage, he blamed them on a lack of qualified personnel and excessive interference by groups in parliament (Uryadovy Kuryer, 1993).

Kuchma coupled his reliance upon bureaucratic methods with calls for order. Upon assuming power, he announced, "We should understand that when people are brought to this situation (social crisis), privatization slogans, social demagoguery, and political speculation can become the beginning of a mass, spontancous upheaval" (Izvestia, 1992, p. 1). In February he issued an appeal for "zhorctkii uryad," which can be translated as "harsh," "strict" or "orderly government" (Holos Ukrainy, 1993b). Stability, of course, is necessary for the overall health of society. However, when combined with a clear disdain for competitive politics and public accountability, these calls may foreshadow the appearance of something more malevolent, especially if the continued crisis sparks public disorder.

Kuchma finally resigned, and Efim Zvyagilsky, a former mine director and mayor of Donetsk enjoying the patronage of Kravchuk, was appointed to replace him. He was less visible than Kuchma, reflecting in part Kravchuk's political preeminence. However, judging from his record in Donetsk, Zvyagilsky also fitted the mold of a "democrat" with an iron fist (Nezavisimost, 1993d). His most notable political accomplishment was to break the Donetsk miners' strike in June, 1993, by promising to hold a public referendum of confidence in the president and the Verkhovna Rada. 'This, of course, was later rejected by Kravchuk, with the apparent acquiescence of his Donetsk ally.

Other officials also support moves consistent with delegative democracy. The head of the parliamentary commission on economic reform argued that Ukraine requires a "professional" legislature of experts, free from the pernicious influence of political parties, and, thereby, free from popular pressures and institutions of accountability (Holos Ukrainy, 1993c). Another member of the commission accused private lobbyists of hindering the government, which, in his opinion, should be left to determine what is best for society (IIolos Ukrainy, 1993d). An informal survey of state bureaucrats at the Institute for State Administration and

\footnotetext{
13. Kuchma was the director of the South Machine Building Works in Dnepropetrovsk, a giant military-industrial plant. One analyst suggested that Kuchma's status as an economic "expert" played a decisive role in his appointment, since "the popular opinion (is) that managers, unlike politicians, do 'real business'. They know the real state of the economy and those measures which should be taken to overcome the crisis." See Kievsky (1993), p. 1.
} 
Self-Government in Kiev reveals support for both democracy and "professionalism" in isolation, but when a tension was posed between these two goals, over two-thirds stated that the participation of the people in the process of making decisions is not necessary if the process is guided by competent leaders. ${ }^{14}$ The message is clear and simple: vote, but you better elect well-qualified individuals and then let them do what they deem best.

Ukraine lacks the institutions to counter movement toward a delegative democracy. The court system, weak and dependent upon the executive, lacks the power and/or will to check growing state power. For example, the court did not review a bank directive, approved by the Cabinet, which fixed the exchange rate, despite claims by the opposition that it violated three statutes of the banking law (PostPostup, 1993c). One independent trade union sought justice for state violation of the labor law at the International Court instead of pursuing the matter through Ukrainian courts (Holos Ukrainy, 1993e). Ukraine, like Russia until December, 1993, also lacks its own constitution, meaning that basic principles of government are left to a panoply of laws and interpretations which do not clearly demarcate separation of powers.

Parties and civic organizations have been, until very recently, ineffective against the "party of power." Political parties in Ukraine-like those in many postcommunist states-suffer from numerous problems: low membership, lack of financial resources, ill-defined constituencies. They have been politically passive, reacting to events and decisions rather than developing their own proposals. Perhaps their greatest defeat was on the adoption of the Ukrainian electoral law, arguably the most important issue to the nascent parties. Despite their attempts to reach a compromise with the "party of power" and create a mixed majoritarian-proportional representation system (like Germany), the adopted law was purely majoritarian, bestowing advantages upon "independent" candidates of the "party of power" (Nezavisimaya Gazeta, 1993, 1994c).

Moreover, some of the "opposition" has been supportive of Kravchuk's maneuvers to centralize power. This is most clearly manifested in the Congress of National Democratic Forces (CNDF), which places first priority on the state, and then (perhaps) democracy. The Republican Party, which composes the largest force in the CNDF, is often referred to as the "president's party," and now that Kravchuk is out of power it has endorsed his bid to become an MP and suggested that he head a new nationalist bloc in parliament (Nezavisimaya Gazeta, 1994d). Larisa Skorik, the leader of the more nationalist branch of Rukh, declared she could support a Ukrainian Pinochet and proposed that Kravchuk adopt harsh presidential rule to restore order to the country (Nezavisimost, 1993e). Even Rukh itself, which later grew vocal in its opposition to Kravchuk, was initially very hesitant to criticize Kravchuk. Its leader Vyadcheslav Chornovil lamented that "Our biggest mistake was to surrender our principles of independence and democracy to other hands which have always been indifferent or hostile to them...An incredible amount of damage to our democratic ideals has occurred" (Vysoky Zamok, 1992). Ultimately, the "national-democrats" were "used like children" by

14. This is based upon 42 responses to written questionnaires distributed by the present author in April, 1993. The respondents were all state officials or individuals planning to enter the administration after a year of graduate training. It is by no means a random sample, but one might expect the bias to fall in a more "democratic" direction since the respondents are disproportionately from Kiev and have been exposed to Western training. I would like to thank the Institute's director, Dr. Bohdan Krawchenko, for his assistance. On another question, only 32 per cent thought that Ukraine needs more pluralism and citizen participation and less state control. 


\section{Delegative Democracy in Russia and Ukraine: P. Kubiček}

the party of power, and one observer commented that their inability to distance themselves from Kravchuk helped precipitate a communist-socialist electoral victory (Ryabchuk, 1994a).

For their part, civic organizations have not been strong sources of opposition to the current regime. In part, Ukraine may suffer from "residual corporatism," since structures from the communist era dominate independent groups in civil society. Leaders of various associations-agricultural groups, business confederations-are part of the new nomenklatura. Trade unions, arguably the organizations with the most potential political power, suffer from sectoral, regional, and ethnic divisions, charges of corruption, and a lack of public confidence. ${ }^{15}$ Moreover, although they are all "independent," most remain loyal to the ancien regime and a large percentage of the union leadership are former obkom or rajkom secretaries who have extensive ties to the economic and political directorate. This is exemplified by Oleksandr Stoian, a former adviser to Kravchuk who has assumed the leadership of the Federation of Trade Unions of Ukraine. Perhaps it is therefore not surprising that this association, to which 97 per cent of workers belong, considered the proposed referendum counter-productive, despite the fact that it was granted as a concession to striking workers (Holos Ukrainy, 1993f).

Finally, support for delegative democracy can be discerned from surveys of public opinion, which show that individuals are most upset over matters of economics and law and order, while few are concerned with the slow pace of democratic political reform. ${ }^{16}$ This is accompanicd by continued faith in statist solutions, as 55 per cent in one survey claimed the state should assume responsibility for the maintenance of society, while only 18 per cent believed that primary responsibility rests with the people themselves. In addition, there are abysmally low feelings of political efficacy. In one survey, only 2 per cent of respondents indicated that they felt they could effectively participate in political life. More prevalent were responses of disillusionment (17.2 per cent), a feeling that they were just as powerless as before (19 per cent), a lack of interest in politics (24.4 per cent).

Participation in civic associations is also very low. According to data from a November, 1991, survey, only 2 per cent of the respondents claimed membership in a civic-political movement or a local civic organization, and 70 per cent stated they belonged to no social organization. This compares unfavorably to the United States, where 75 per cent of individuals belong to some type of civic organization. Moreover, on virtually all counts, civic participation has dropped from the levels of 1989, reflecting, perhaps, growing feelings of alienation and hopelessness (Golovakha, 1992). All of these indicators bode well for delegation as opposed to participation.

Recent events in Ukraine have brought some changes to the political arena. In the July, 1994, presidential run-off between the two Leonids, Kuchma prevailed and became president. Not surprisingly, his program was full of mutually exclusive promises, resulting in difficulty in pinning him down to any particular

15. According to a poll conducted in May, 1993, 40.6 per cent of respondents stated they had no confidence in unions, whereas only 2.7 per cent expressed absolute confidence (see Nezavisimost, 1993f).

16. When asked to name what made them the most unhappy in $1992,72.2$ per cent said rising prices, 22.2 per cent a deficit of necessary products, 21 per cent a loss of order and stability, and 17.8 per cent a fall in output. Only 4.4 per cent cited the slowing of democratic reform. Unless otheswise stated, all figures come from surveys conducted by the Institute of Sociology in early 1993. Again, thanks to Eugene Sinnitsyn for providing me access to this data. 
program. ${ }^{17}$ Judging from his initial moves as president, however, it appears that the style of leadership, if not the content itself, has not significantly changed. Like Kravchuk, Kuchma belongs to no political party. ${ }^{18}$ One of his first presidential orders, "On Urgent Measures to Strengthen the Fight against Crime," was condemned by three Ukrainian legal groups for violating both Ukrainian law and international human rights standards. Kuchma's response was "I know that this order is not to everyone's liking. The majority of simple people who work for a living supported it. As for the 'fat cats,' this order is a fish in their eye [??]" (Novosti, 1994, p. 2). Kuchma, of course, in no way consulted these "simple people," and instead seems to assume implicitly that since he was elected his policies ipso facto have public support. Moreover, he has also taken steps to gain greater executive power and subjugate the popularly-elected chairmen of regional councils to his own authority, which violated a previous understanding he had arranged with other leaders and de facto reanimates the prefect system used by his predecessor (Nezavisimaya Gazeta, 1994e). In sum, one could argue that the technocratically-minded Kuchma, now armed with democratic legitimacy, may push Ukraine further along the path toward delegative democracy.

Nonetheless, it is still not clear that this path should be abandoned. Perhaps advocates of delegative democracy or "myaky" authoritarianism are right: pluralist democracy is inappropriate for current conditions and should be pursued only once the crisis has been overcome. In the next section, therefore, I will examine what are the likely impacts of this course and what, if any, alternatives would be superior.

\section{Latent Dangers and Possible Alternatives}

At first blush, delegative democracy may seem to be the appropriate political response to the crisis gripping Russia, Ukraine, and other post-communist states. Unlike pure authoritarianism, it does not rely exclusively on raw power and can claim some fidelity to certain democratic principles, giving the leadership an aura of legitimacy. However, unlike liberal democracy, derided as a system of endless talk and debate, delegative democracy promises strong, authoritative leadership. Decisions can therefore be made more swiftly and in accordance with national, not particular, interests.

Despite its claims to avoid the uncertainties of Western-style democracy, delegative democracy entails risks of its own. Appeals for enlightened leaders-philosopher-kings-who pursue "the good" can be traced back to Plato, yet attempts to realize them have often brought something more malevolent. Atrocities of all sorts have been committed for the greater good of the people. Unrestrained power opens itself up to abuse. The editor of Nezavisimaya Gazeta suggested that Yeltsin's actions, despite their good intentions, have historical parallels with those of Nicholas II and Lenin, both of whom dissolved elected assemblies and moved toward authoritarianism and repression. The losers on both occasions were the Russian people (Tretyakov, 1993). A repeat of these events is not out of the question. One writer remarked:

17. For example, he promised to stop inflation and implement real reforms, but also assured his supporters in the state economic sector that they would enjoy more subsidies.

18. Reflecting the weakness of Ukrainian political parties, only one of the original seven presidential candidates, Oleksandr Moroz, was clearly connected to any political party (Moroz is leader of the Socialist Party). 


\section{Delegative Democracy in Russia and Ukraine: P. Kubiček}

It is easier to destroy communism than to create a viable democratic organism. In the process of transformation rips in the social fabric are unavoidable, as people are placed on different sides, and one's own view of the present is taken as the truth. In this moment there is nothing more dangerous than for the state to accept only one point of view as truth.... (Kuvaldin, 1993, p. 2).

Moreover, two claimed advantages of delegative democracy-authoritative leadership and adoption of "correct," "scientific" solutions-are grossly overstated. Presidents in a delegative democracy are simultaneously ommipotent and impotent. On paper, they are able to issue edicts, decrees, and directives on a wide range of social questions. Implementation, however, is a problem. In order for reforms to succeed, presidents need the supporting actions of other social actors. However, because of the "self-indulgent solitude" of policy-making, plus the weakness of institutions it has accentuated, cooperation with other actors is difficult (O'Donnell, 1992). Orders from the top are ignored, impossible to implement, or may contradict decrees from other bodies, creating more chaos than order. Certainly this has been the case in both Russia and Ukraine. This predicament recalls Gorbachev's efforts to create a revolution from above, which failed because forces from below either dragged their feet or rushed on ahead, creating more political instability. One solution to this problem, of course, is a return to Stalinism, but this is a prospect that few would endorse.

Delegative democracy's implicit promise of magical policy-making, which will bring technical knowledge to politics to devise "correct" solutions, is also dubious. Cynically, one can suggest that the leadership will be predisposed to seek advantages for itself, and not policies for the good of the country. Policies are not subject to debate in the "free marketplace of ideas," which vaccinates representative democracies against gross mistakes (O'Donnell, 1992, p. 9). Moreover, pure "technocratism"-reflected in "shock therapy" solutions-has not been politically feasible for any Russian or Ukrainian leader. A better solution, which corresponds to the style of policy-making in representative democracy, may be for compromises and shared responsibility, which bolsters prospects for implementation and political stability.

Finally, delegative democracy makes the construction of lasting democratic institutions problematic. In other words, delegative democracy is unlikely to work as a first step toward democratic consolidation. It deepens the defects imputed to democratic institutions by hampering their development. Thus, it becomes a selffulfilling prophecy: it emerges amidst claims that other institutions are weak and then it imposes conditions which weaken them further, requiring its continued existence. For example, in Ukraine political parties have been virtually shut out of the political process. Partially as a consequence, they suffer from abysmally low scores of public confidence because the public believes they are unable to accomplish anything. ${ }^{19}$ Delegative democracy thus creates a vicious cycle, effectively removing liberal democracy as an option. Moreover, when and if the executive needs legislative support, it is bound to find a resentful congress that does not feel political responsibility. This fosters the decline in prestige of all parties and politi-

19. Throughout 1993, polls revealed that political parties were trusted less than the president or the legislature. For example, in a survey conducted by the pro-reform group "Democratic Initiative," only 0.6 per cent of the respondents said they completely trusted political parties, whereas 60.3 per cent claimed they did not trust them at all. Evidence of their lack of exposure (irrelevance??) is that a nonexistent party, the Party of Order and Justice, was third in popularity among parties (see Ukrainsky Ohladach, 1994). 
cians, who are caught in a "colossal prisoner's dilemma," since it is very difficult (if not impossible) to build political bridges and form workable coalitions (O'Donnell, 1992, pp. 13-14). This, in turn, contributes to governmental gridlock, which bolsters claims for more authoritarian rule.

In O'Donnell's words, the result is a "terrible drama" $(1992$, p. 15). Countries lacking a democratic tradition have to cope with the negative legacies of their authoritarian past in the midst of a deep social and economic crisis. They are placed in an unenviable position: effective institutions and a democratic political culture cannot be built overnight, yet the pressures of the crisis require institutions which can deal with a number of urgent problems. Thus, individuals may claim that delegative democracy or outright authoritarianism, while risky, is the only possible path to avoid further social chaos.

This is a claim that proponents of democratization must take seriously. One cannot, as some democrats might, exclusively appeal to the intelligence and goodwill of political elites and voters to preserve democratic principles. This is simply too utopian. Moreover, the conclusion that more time is needed to make democracy work-reasonable though it is - rings hollow as individuals believe that they or their country as a whole has no time to waste. Can democracy offer anything more than empty promises?

Fortunately, the experience of Eastern Europe and Latin America shows that it can. Granted, nations in both of these regions still face immense problems. However, in Latin America, Chilc and Uruguay, two states whose system approximates a representative democracy, have fared better than Argentina, Brazil, or Peru, which have been "unmitigated disasters in terms of economic and social policy" (O'Donnell, 1992, p. 11). ${ }^{20}$ The latter have suffered through "reform packages" imposed from above, which have only worsened the initial problems. In contrast, in Uruguay the President has been forced to go through Congress, and the resultant incremental, more modest policies have produced economic improvement. Meanwhile, most East European states are parliamentary democracies. Constitutionally, parliaments dominate over presidents, whose powers are severely restricted in comparison to those of Yeltsin or Kravchuk (McGregor, 1994). ${ }^{21}$ Nonetheless, many-if not allhave made more progress than Russia or Ukraine on issues of political and economic reform, despite changes in govermment or shifts in coalitions. ${ }^{22}$

At this point, we might reflect on what can be done to bolster prospects for democratic consolidation in Russia and Ukraine. One obvious suggestion is the

20. One can, of course, argue that Chile and Uruguay started out with inherent advantages over the others. The key point here, however, is that representative democracy is not per se a barrier to economic success in nations with acute problems.

21. For example, in none of the 15 states McGregor examined did the president enjoy unqualified power to issue decrees or the right to dissolve parliament. Those presidents commonly thought to have extraordinary power-Walesa in Poland, Tudjman in Croatia-benefit from personal credibility and non-constitutional provisions.

22. Again, one may argue that this success has been achieved due to the relative (compared to Russia or Ukraine) lack of crisis in these states, which has allowed democracy to function. However, governments in these states have been able to implement decisions in difficult circumstances and, for the most part, enjoy public support. The case of Poland is particularly instructive. Despite numerous changes in government, Poland, while no utopia, is an economic success story and now enjoys the fastest rate of economic growth in Europe. Arguably, the creation of representative democracy, based upon political parties, has contributed to regime stability by lengthening time horizons for political actors and bolstering feelings of political efficacy among the citizenry. Nonetheless, it is difficult to disentangle the two variables-pre-existing conditions or the new political system-as the "cause" of political and economic successes. At minimum, however, representative democracy should not be assumed to be analogous with ineffective government. 
creation of a multi-party system with capable political parties. Russia has already moved in this direction because its electoral law, stipulating that half of all parliamentarians will come from voting on party lists, encourages formation of political parties. Those parties currently in the State Duma now need to consolidate their programs and constituencies and seek political partners. Education and the gaining of political visibility will be important tasks for these parties. They must also assume some political initiative, i.e. introduce legislation, public opinion campaigns, etc., to prove their political acumen to a still skeptical electorate. Prospects in Ukraine, unfortunately, are worse. There, elections were held under the majoritarian system, and 89 per cent of all candidates were independents (Uryadovy Kuryer, 1994). As long as this system exists, Ukraine will be captive to the politics of personality, and "independents," unburdened by platforms or intraparty discipline, will be given free reign to interpret their "mandates" as they see fit.

Constitutional reform is also a priority. If one insists upon maintaining some form of presidentialism, a clear separation of powers must exist between all three branches of government. Presidential power of appointment should be restricted and/or subject to legislative approval. Rule by decree should be forbidden or, at minimum, severely circumscribed. Powers to dissolve parliament should be very carefully restricted. Parliament should assume the lead in creating a new government.

I would, however, go a step further and recommend a significant curtailment in presidential power. The role of the German president is perhaps instructive. He is elected by an electoral college and possesses symbolic power as a source of national unity. His political role, however, is highly circumscribed. The prime minister, or chancellor, who is elected by parliament, is the major political actor, but his position depends upon the support of his party and coalition partners. He is sufficiently authoritative to govern effectively, but abuse of power is checked. This system entirely avoids the problem of dual executives which has plagued Russia, Ukraine, and France.

Finally, no democracy will be strong without a foundation within society. An active citizenry and a pluralist society serve as guards against the emergence and persistence of delegative democracy or other still more authoritarian systcms. However, as Ralf Dahrendorf observes, the "hour of the citizen" will require a great deal of time to be realized (Dahrendorf, 1990). Autonomous interest and civic associations - the hallmark of civil society-are not built overnight. Nonetheless, certain steps can expedite their development. The first is the creation of a free market economy, which will break society's dependence upon the state and foster the rise of interest groups and organizations. The second is decentralization of power, which would give more authority to localities and support local initiatives. Organizations would thus be able to have an effect on policies at the local level, and this would provide an incentive for increased political participation and raise feelings of political competence. Finally, interest associations could be brought into the processes of policy-making and implementation, analogous to the neo-corporatist arrangements in many countries in Western Europe. This, of course, would not be a panacea, but it would help foster notions of shared responsibility and teach the value and necessity of compromise.

The transformation of communist societies will require both extraordinary patience and political skill. The road from communism to democracy is longer and bumpier than the road from democracy to communism. Western models may not be able to be transplanted in post-communist soil. Movement to democracy will 
be slow and halting, but that does not mean that solutions such as delegative democracy, which harken backwards to authoritarianism, should or must be adopted. Despite its claims to be a means to rescue society, it presents dangers of its own and makes the building of democratic institutions even more difficult. If, as the record shows, a representative, competitive, pluralist democracy can function in states experiencing deep social and economic crises, then trends toward delegative democracy, whether as a "necessary evil" or "national savior," should not be welcomed as a positive sign in post-communist political development.

\section{References}

Bernhard, Michael (1993) "Civil Society and Democratic Transition in East Central Europe," Political Science Quarterly, 108 (Summer 1993), pp. 307-326

Bova, Russell (1991) "Political Dynamics of the Post-Communist Transition: A Comparative Perspective," World Politics, 44 (October 1991), pp. 113-138

Bujvol, Boris (1992) "Sotsialna patopsykholohya bilshovyzmu ta problemy yiyi podolannya v natsionalni svidomosti," Ukrainsky Chas, 2(10), pp. 34-36

Cline, Mary, Corning, Amy, and Rhodes, Mark (1993) "The Showdown in Moscow: Tracking Public Opinion," RFE/RL Research Report, (October 29, 1993), pp. 11-16

Corning, Amy (1993) "Public Opinion and the Russian Parliamentary Elections," RFE/RL Research Report, (December 3, 1993), pp. 16-23

Dahrendorf. Ralf (1990) Reflections on the Revolution in Europe, London: Chatto and Windus

Di Palma, Giuseppe (1990) To Craft Democracies: An Essay on Democratic Transitions, Berkeley: University of California Press

Diamond, Larry and Plattner, Marc (eds.) (1993) The Global Resurgence of Democracy, Baltimore: John Hopkins University Press

Diamond, Larry, Linz, Juan, and Lipset, Seymour (eds.) (1988) Democracy in Developing Countries, Boulder: L. Rienner

Ekiert, Grzegorz (1991) "Democratization Processes in East Central Europe: A Theoretical Reconsideration," British Journal of Political Science, 21 (July 1991), pp. 285-313

Golovakha, Evhen (1992) "Politychna zaluchenist naselennia: po informovanist, akyvnist, kompententnist," Politolohichny Chytannya (Kiev), 2, pp. 14-22

Gualtieri, Dominic (1993) "Russia's New 'War of Laws'," RFE/RL Research Report, (September 3 , 1993) pp. $10-15$

Holos Ukrainy (1993a) "Moya pozytsiya-vzayemovyhidne spivpobithytsvo," (September 4, 1993) p. 4.

Holos Ukrainy (1993b) "Ukraine treba zhorctkii uryad," February 3, 1993, p. 1

Holos Ukrainy (1993c) "V. Pylpchuk: potribni profesionaly," August 21, 1993, p. 4

Holos Ukrainy (1993d) "Plan diyi uryadu," February 3, 1993, p. 2

Holos Ukrainy (1993e) "U Haagu-pozov na parlament," September 15, 1993, p. 2

Holos Ukrainy (1993f) "Pozytsiya profspilok," August 13, 1993, p. 3

Huntington. Samuel (1991) Third Wave: Democratization in the Late Twentieth Century, Norman: University of Oklahoma Press

ITAR-TASS (1993) in English, reported in Foreign Information Broadcast Service, Daily Report: Central Eurasia, May 5, 1993, p. 27

Izvestia (1992) "Pravitelstvo Ukrainy poluchayet polnomochiya za vedenie diktatury v ekonomike," November 20,1992, p. 1

Izvestia (1993a) "President prekrashchayet funtsii sezda i parlamenta," September 22, 1993, p. 1

Izvestia (1993b) "Profsoiuznye bossy igrayut v starye partiinye igry," May 19, 1993, p. 4

Izvestia (1993c) "Thatcher, Pinochet, ili Andropov," November 4, 1993, p. 4

Izvestia (1993d) "L. Kravchuk vozglavil novy stary Kabinet ministrov," October 1, 1993, p. 4

Izvestia (1994) "Shkola kommunizma \& gosudarstvennoi dyme," February 27., 1994, p. 4

Jowitt, Ken (1992) New World Disorder: The Leninist Extinction, Berkeley: University of California Press

Kievsky, Vladimir (1993) "Prime Minister Will Have to Become a Politician," Kiev Times, 2, April 1993, p. 1

Korotsei, Vasyl (1993) Presentation (untitled) at the conference "Authority and Property in Ukraine: Current Problems and Future Prospects," Lviv, Ukraine (February, 1993)

Kuvaldin, Viktor (1993) "Myortvy dom," Nezavisimaya Gazeta, October 12, 1993, p. 2

Kuzmishchev, Aleksandr (1993) "Rossiya skvoz 'Latinoamerikanskuyu prizmu'," Nezavisimaya Gazeta, September 2, 1993, p. 2 


\section{Delegative Democracy in Russia and Ukraine: P. Kubiček}

Lysenko, Vladimir (1993) "Na razvilke dvukh dorog," Nezavisimaya Gazeta, November 11, 1993, p. 1 McGregor, James (1994) "The Presidency in East Central Europe," RFE/RL Research Report, January 14, 1994, pp. 23-31

Migranyan, Andranik (1993) "Avtoritarny rezhim v Rossii: Kakovy perspektivy?" Nezavisimaya Gazeta, November 4, 1993, p. 1

Nezavisimaya Gazeta (1993) "Oppozitsiya edinodushno kritikuyet zakon o vyborakh," December 4, 1993, p. 3

Nezavisimaya Gazeta (1994a) "Konstitutsionny sud vypolnil poruchenie prezidenta," February 3, 1994, pp. $1-2$

Nezavisimaya Gazeta (1994b) "Presidentskaya partiya: Yeltsin i Gaidar vstupayut v skrytoe protivoborstvo," February 17, 1994, p. 1

Nezavisimaya Gazeta (1994c) "Vlast govorit o vyborakh, oppozitsiya—o reformakh," January 4, 1994, p. 3

Nezavisimaya Gazeta (1994d) "Leonid Kravchuk vozvrashchaetsya v aktivnuyu politiky," September 2,1994, p. 1

Nezavisimaya Gazeta (1994e) "Leonid Kravchuk podchiyaet sebe ispolnitelnuyu vlast'," August 17, 1994, p. 3

Nezavisimost (Kiev) (1993a) "Leonid Kravchuk: Gosudarstvo-eto my." June 23, 1993, p. 2

Nezavisimost (1993b) "Est kusochek pravdy v shutkakh Kuchmy?" February 10, 1993, p. 1

Nezavisimost (1993c) "Vesna. Premer sovetuyet partiyam uigti v otctavku," March 3, 1993, p. 1

Nezavisimost (1993d) "Efim Zvyagilsky-samy pervy iz vtorykh," July 21, 1993, p. 4

Nezavisimost (1993e) "Pani Skorik blagoslovlyaet ukrainskogo Pinocheta," May 15, 1993, p. 2

Nezavisimost (1993f) "Doverie k vlasti-na urovne trotuapa...," June 23, 1993, p. 2

Novosti (Kiev) (1994) "Kuchma nachal borbu s prestupnostyu, no...," July 28, 1994, pp. 1-2

O’Donnell, Guillermo (1992) "Delegative Democracy?" Working Paper \#172, Kellogg Institute for International Studies, University of Notre Dame March 1992

O'Donnell, Guillermo (1993) "On the State, Democratization, and Some Conceptual Problems: A Latin American View with Glances at Some Postcommunist Countries," World Development, 21 (August 1993), pp. 1355-1369

O'Donnell, Guillermo, Schmitter. Philippe, and Whitehead, Laurence (eds.) (1986) Transitions from Authoritarian Rule, Baltimore: John Hopkins University Press

Pastukhov, Vladimir (1993) "Komedno-operny avtoritarizm v Rossii," Megapolis-Express, October 20, 1993, p. 19

Pochentsov, Georgii (1993) "Spetsialisty i govoruny," Nezavisimost, February 17, 1993, p. 2

Post-Postup (Lviv-Kiev) (1993a) "Boris Sobolyev: Ya ne znayu v Ukraini takoyi syly, yaka by zmusyla kupon stoyaty," August 25-30, 1993, p. 2

Post-Postup (1993b) "Partytura," June 15-21, 1993, p. 3

Post-Postup (1993c) "Uryad Kuchmy: pity, shchoby lyshytysya," September 14-21, 1993, p. 2

Post-Postup (1993d) "Partytura," August 30-September 6, 1993, p. 4

Post Postup (1994) "Ukrainski uryadovtsi vvazhayut, shcho kinets hyperinflatsiyi tsilkom mozhe staty pochatkom reform," May 21-26, 1994, p. B2

Przeworski, Adam (1986) "Some Problems in the Study of Transition to Democracy," in O'Donnell et al. (eds.) Comparative Perspectives, pp. 47-63

Przeworski, Adam (1991) Democracy and the Market: Political and Economic Reforms in Eastern Europe and Latin America, New York: Cambridge University Press

Ryabchuk, Mykola (1992) "Authoritarianism with a Human Face?" East European Reporter, 5 (November-December, 1992), pp. 52-56

Ryabchuk, Mykola (1994a) "Chy isnuye v Ukraini Partiya Vlady?"' UNIAN-Polityka, May 10-16, 1994, pp. 3-5

Ryabchuk, Mykola (1994b) "Between Civil Society and/or The New Etatism," in Michael Kennedy (ed.) Envisioning Eastern Europe after Communism: Ideology and Identity in Transformation, Ann Arbor: University of Michigan Press (forthcoming)

Schumpeter, Joseph (1950) Capitalism, Socialism, and Democracy, New York: Harper

Shokhina, Viktoria (1993) "Na vsekh parakh cherez boloto," Nezavisimaya Gazeta, October 9, 1993, p. 2

Slater, Wendy (1993) "Head of Russian Constitutional Court under Fire," RFE/RL Research Report, June 25,1993 , pp. $1-5$

Slater, Wendy (1994) "Russia's Plebiscite on a New Constitution," RFE/RL Research Report, January 21,1994 , pp. $1-7$

Slater, Wendy and Tolz, Vera (1993) "Yeltsin Wins in Moscow but May Lose to the Regions." $R F E / R L$ Research Report, October 8, 1993, pp. 1-7

Tolz, Vera (1993) "The Moscow Crisis and the Future of Democracy in Russia," RFE/RL Research Report, October 22, 1993, pp. 1-9 
Delegative Democracy in Russia and Ukraine: P. Kubiček

Tolz, Vera (1994) "Problems of Building Democratic Institutions in Russia," RFE/RL Research Report, March 4, 1994, pp. 1-7

Tretyakov, Vitalii (1993) "Ikh vsekh nuzhno ostaovit," Nezavisimaya Gazeta, September 23, 1993, p. 1

Ukrainsky Ohlyadach (1994) "Politychna Panorama 93: Vlada, Partiyi, Polityky," 2, pp. 7-8

Uryadovy Kuryer (1993) "Intervyu z premerom," May 15, 1993, p. 3

Uryadovy Kuryer (1994) "V tsentralnoi vybornoi komisiyi," Februrary 26, 1994, p. 1

Ustyuzhanin, Vasily (1993) "Na konstitutsionnom pole vzoshlu ozimye," Komsomolskaya Pravda, November 10,1993 , p. 1

Vysoky Zamok (Lviv) (1992) "Pro sotsialno politychny stan v Ukraini i zavdannya Rukhu," December 8,1992, p. 1

Wishnevsky, Julia (1993) "Liberal Opposition Emerging in Russia?" RFE/RL Research Report, November 5,1993 , pp. 5-11 